\title{
A hidrogén üzemanyagcellák katonai célú felhasználásának lehetőségei
}

\section{A VILLAMOS ENERGIÁRÓL ÁLTALÁBAN}

Általában az emberiség és Magyarország is évről évre nagyobb mértékben függ a villamos energiától. A világ energiaigénye is folyamatosan emelkedik, de talán ennél is fontosabb a tény, hogy a villamosság aránya az összes energiafelhasználáson belül is folyamatosan nő [1]. Világviszonylatban az elmúlt 40 évben a teljes energiafelhasználás megduplázódott, míg a villamosság aránya ezen időszak alatt a négyszeresére nőtt. Ezt a globális növekedést elsősorban a fejlődő országok gazdasági robbanása idézte elő, de szinte minden fejlett ország energiaigénye is megnövekedett. Magyarország primer ${ }^{1}$ energia felhasználása - a gazdaság szerkezeti átalakulása miatt - az elmúlt 10 évben kis mértékben ugyan még csökkent is, de a villamos energia iránti igény mégis $30 \%$-os növekedést ${ }^{2}$ mutat ugyanebben az időszakban.

A szekunder energiapiacon ${ }^{3}$ a villamos energia azért bír egyre nagyobb jelentőséggel, mert az erőművekben viszonylag jó hatásfokkal tudjuk előállítani a primer forrásokból, illetve jó hatásfokkal tudjuk továbbítani ${ }^{4}$ és végső formájában felhasználni is. A villamosság még nagyobb ütemű térnyerésének jelenleg két technológiai akadálya van:

- Bár folyamatosan nő a megújuló primer források aránya a termelésen belül, a villamosság $75 \%$-át jelenleg is fosszilis hordozók elégetésével nyerjük, ami súlyosan károsítja a földi bioszférát.

- A villamos energiát nem tudjuk nagy mennyiségben és gazdaságosan tárolni.

$A z$ erőművek környezetszennyezése nem témája ennek a munkának, de a villamos energia tárolása annál inkább. Erre ugyan számos megoldás létezik, de a legtöbb ilyen (pl. az ún. szivattyús tározóké) rendkívül rossz hatásfokkal rendelkezik. A leggyakoribb mód, az akkumulátoros tárolás hatásfoka lényegesen jobb, pedig az általánosan használt váltakozó áramot a tároláshoz egyenárammá kell alakítani, ami veszteséggel jár, majd az újbóli felhasználáskor az egyenáramot többnyire váltakozóvá kell alakítani. Az akkumulátoros tárolással kapcsolatban azonban jelen technológiai szinten három igen súlyos probléma fogalmazható meg:

- az akkumulátorok gyártása meglehetősen drága, a villamosság tárolásának költsége ezért nagyságrendileg nagyobb az előállításnál;

- az akkumulátorok gyártásához használt anyagok (lítium, ritkaföldfémek) bányászata rendkívül pusztító hatással van a környezetre;

- az akkumulátorok fajlagos energiasűrűsége ${ }^{5}$ a kőolajszármazékokhoz képest igen rossz. Jelenleg ez a fő akadálya pl. a villamos autók terjedésének is.

\section{A HIDROGÉN ÜZEMANYAGCELLA MÜKÖDÉSE ÉS JELLEMZÖI}

A hidrogén energiahordozóként történő felhasználásának a legkézenfekvőbb módja az elégetés, így erőművi módszerrel $^{6}$ akár villamosságot is előállíthatnánk a segítségével, de szerencsére az üzemanyagcellák révén kínálkozik erre egy direkt mód is. Az üzemanyagcellák elvi alapjai már a XIX. század első felétől ismertek, de komolyabban csak az 1970-es évek, vagyis az első olajválság óta kutatják a gyakorlati felhasználásukat. Az első kereskedelmi célú alkalmazásuk az 1990-es évekre tehető [2]. Üzemanyagcella alatt egy olyan kémiai áramforrás értendő, ami a megfelelő anyagok folyamatos biztosítása mellett folyamatosan képes áramot előállítani, tehát az akkumulátorokkal vagy galvánelemekkel szemben (legalábbis elvben) soha nem merül le. A felhasznált üzemanyag elméletileg, sőt már a gyakorlatban is sokféle lehet ${ }^{7}$, de a legegyszerűbb és leggyakoribb megoldás a hidrogén alkalmazása, ezért a továbbiakban kimondottan a hidrogéncellákról lesz szó.

A hidrogént használó üzemanyagcellák az ún. PEM cellák ${ }^{8}$. Ezek működését az 1. ábra alapján lehet megismerni. A nagy nyomású hidrogén $\left(\mathrm{H}_{2}\right.$ gáz) az anódra kerül, ahol a katalizátor hatására leadja az elektronjait. A protonok átha-
ÖSSZEFOGLALÁS: A hidrogénüzemú PEM cella egy olyan technológia, amelyben Magyarország számára is jelentős alkalmazói és fejlesztési potenciál rejtőzik. A haditechnikában történő felhasználása olyan eszközöket eredményezhet, amelyek bizonyos egyedülálló tulajdonságaik által jelentős múveleti előnyt biztosíthatnak az alkalmazó katonai egységek számára. $A z$ MTA Természettudományi Kutatóközpontjának Anyag- és Környezetkémiai Intézet révén Magyarország önállóan is sikerre vihet bizonyos részkutatásokat vagy létrehozhat magas műszaki színvonalú haditechnikai eszközöket.

KULCSSZAVAK: PEM cella, hidrogénüzem, villamosenergia-ellátás, haditechnika, MTA TTK AK
ABSTRACT: The hydrogen-powered PEM fuel cell is a technology having considerable application and development potential for Hungary too. Its application in military technology can result in devices that, by virtue of their some unique features, can bring significant operational benefits for the military units that use them. Through the Institute of Materials and Environmental Chemistry of the Research Centre for Natural Sciences of the Hungarian Academy of Sciences, Hungary can independently conduct certain smallerscale researches or create high-tech military equipment.

KEY WORDS: PEM fuel cell, hydrogen-powered, electricity supply, military technology, MTA TTK AK

\footnotetext{
* Mk. ezredes, MH Modernizációs Intézet, osztályvezető, NKE doktorandusz, ocskay.istvan@hm.gov.hu. ORCID: 0000-0003-0279-8215

** Mk. alezredes, MH Modernizációs Intézet, kiemelt főtiszt, NKE doktorandusz, vegvari.zsolt@hm.gov.hu. ORCID: 0000-0003-2543-6049
} 


\section{AZ ÜZEMANYAGCELLA ÉS AZ AKKUMULÁTOROK ÖSSZEVETÉSE}

A villamos energia jelenleg mind fosszilis, mind nukleáris, mind megújuló forrásokból elérhető áron állítható elő, és távvezetékekkel minimális veszteség mellett továbbítható. Ugyanakkor a villamos energiára ott is van igény, ahol nincsen villamos infrastruktúra. Vagy, mert nem érte meg kiépíteni, vagy technológiailag nem is lehetséges (lásd e-mobilitás), vagy valamilyen környezeti vagy emberi tevékenység (pl. árvíz, háború) miatt megrongálódott, megsemmisült. Ilyenkor helyben kell megtermelni az áramot, az erőműveknél jóval költségesebb aggregátorokkal, vagy „tárolt" formában kell odaszállítani. Ez utóbbi területen napjainkban a PEM cellák az akkumulátorokkal közvetlenül versenyeznek. A felhasználás viszonylagos egyszerűsége miatt jelenleg az akkumulátorok az elterjedtebbek, de igazából a PEM cellák is hasonló technikai paraméterekkel bírnak, illetve számos tekintetben jobbak is.

A hidrogéncellák terjedésének napjainkban az ár a legfontosabb akadálya. Az e-mobilitás területén jól látszik, hogy ha a teljes hajtáslánc tömeg/teljesítmény arányait vizsgáljuk, a hidrogénes autók már versenyképesek a hagyományos autókkal is, az akkumulátoros meghajtásnál pedig jóval nagyobb hatótávot és gyorsabb feltölthetőséget biztosítanak. Ugyanakkor az magas áruk mellett ellenük szól az is, hogy sokan idegenkednek a hidrogéntől és veszélyesnek tartják, illetve a hidrogén előállítására és elosztására szolgáló infrastruktúra is meglehetősen beruházás-igényes.

A hidrogénes PEM cellás rendszereknek napjainkban elsősorban a hosszú távú lokális, hálózattól független villamos ellátásban van óriási előnye. Megfelelő számú napelemmel vagy más megújuló forrással és akkumulátorokkal már most is megoldható egy objektum teljes villamos energetikai függetlensége, de rossz időben csak az igen drága akkumulátorok kapacitásának határáig. A hidrogén tárolásának ugyanakkor csak a viszonylag olcsó tartályok kapacitása szabhat gátat. Már Magyarországon is működik több olyan épület, illetve távközlési csomópont, ahol a napelemek, akkumulátorok és a hidrogén hármasával biztosítanak azoknak lényegében egész évben, hálózatfüggetlen módon villamos áramot.

A hosszú távú villamosenergia-tárolás kitűnő példája még a német U 212-es dízel-elektromos tengeralattjáróosztály is, ahol az akkumulátorok csak kisegítő jelleggel vannak jelen a fedélzeti gépészetben. A hosszabb távú víz alatti haladáshoz szükséges villamosságot PEM cellákból nyerik, a hidrogént pedig a felszíni haladáskor a dízelmotorokra kötött generátorokból nyert villamosság segítségével, vízbontással fejlesztik [3].

Szintén előnyben van az üzemanyagcella az akkumulátorokkal szemben, ahol valamilyen okból a belső égésű motorral hajtott aggregátorok nem alkalmazhatóak. Ilyen esetekben az akkumulátorokat nem lehet újratölteni, de amennyiben a hidrogén, tüzelőanyagként folyamatosan biztosítható, a PEM cellás áramforrások üzemidejének elvben csak az elektródák és a katalizátor degradálódása szab határt. Említésre méltó még, hogy bár az üzemanyagcella hatásfoka is hőmérsékletfüggő, ez elhanyagolható az akkumulátorokhoz képest, amelyek típustól függően fagypont alatt a névleges teljesítményüknek csak alig 10-40\%-át képesek leadni [4].

\section{A HIDROGÉNCELLÁK LEHETSÉGES ALKALMAZÁSAI}

Napjainkban a hidrogén tipikus felhasználási területének számít már a különféle szállítási feladatok ellátása, beleértve a személy- és teherszállító járműveket, hajókat, vasúti kocsikat, repülőgépeket anyagmozgató berendezéseket, továbbá olyan stacioner berendezéseket, mint hálózatpótló generátorok vagy a háztartási melegvíz, fütés és villamosenergia-előállító mini erőművek (mini-CHP ${ }^{12}$ ). 2017ben ${ }^{13}$ Európában $350 \mathrm{db}$ személygépkocsi, $47 \mathrm{db}$ autóbusz, $18 \mathrm{db}$ tehergépkocsi és $116 \mathrm{db}$ targonca hajtóanyaga volt a hidrogén, amelyet ezek az eszközök mindösszesen 39 töltőállomásból tudtak vételezni. Emellett $1112 \mathrm{db}$ olyan mikro erőmű üzemelt a kontinensen, amelyet szintén hidrogén hajtott [5].

A hidrogéncellák alkalmazásának előnyei a közlekedési eszközök tekintetében jelentkeznek leglátványosabban. Eltekintve a jelenlegi gyér hidrogénkút hálózattól, egy átlagos hidrogénhajtású személygépkocsinak 500-600km a hatótávolsága, és akár 3-5 perc alatt feltölthető a jármű hidrogéntartálya [6]. Tehergépkocsiknál még látványosabbak ezek az értékek, ott akár 1900 km megtételére elég a fedélzeten tárolt 100-120 kg-nyi hidrogén, 15 perc alatt fel lehet $100 \%$-osan tölteni a tartályokat, akár kétszeres nyomatékot is produkálnak a villanymotorok egy hagyományos dízelmotorhoz képest. Fajlagos fogyasztásuk 0,7-1 kg/100 km, ahol jelenleg $1 \mathrm{~kg}$ hidrogén ára (természetesen kutaktól függően) 9-11 Euró között mozog, amely arányait tekintve gazdaságossá teszi a járművek üzemeltetését. A korábban is említettek szerint jelenleg a járművekbe szerelt üzemanyagcellák ára, illetve azok tömege, ami megnehezíti ezen eszközök elterjedését.

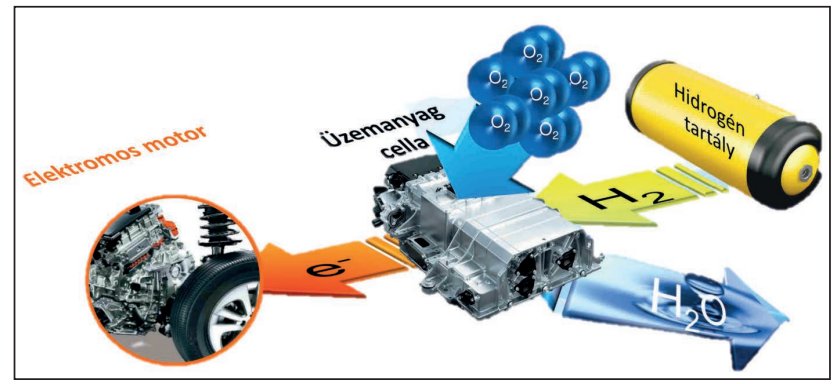

2. ábra. A hidrogéncellás hajtás sematikus ábrázolása

Nézzünk néhány, már megvalósult példát, a hidrogén meghajtású autók legnagyobb fejlesztője, a Toyota jóvoltából [7]. A Toyota Mirai hidrogéncellás, hibrid hajtású személyautó, amelyet a gyár már 2016 óta gyárt, fejleszt, jelenleg már 154 kW-s teljesítménnyel rendelkezik 550 km-es hatótávolság mellett. A jármű kialakítása megegyezik egy hagyományos 4 ajtós szedánéval, a csomagtere 361 literes, hossza 4,89 méter.

\section{3. ábra. Toyota Mirai egy hidrogéntöltő állomáson}

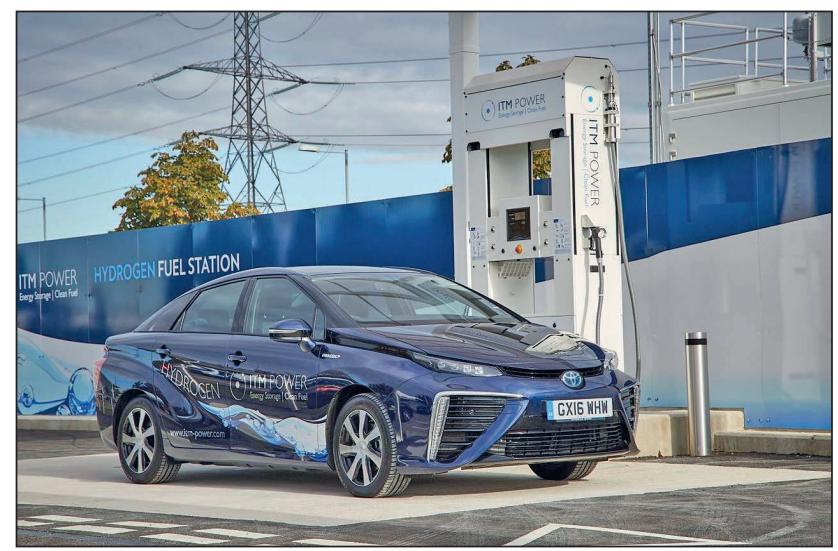




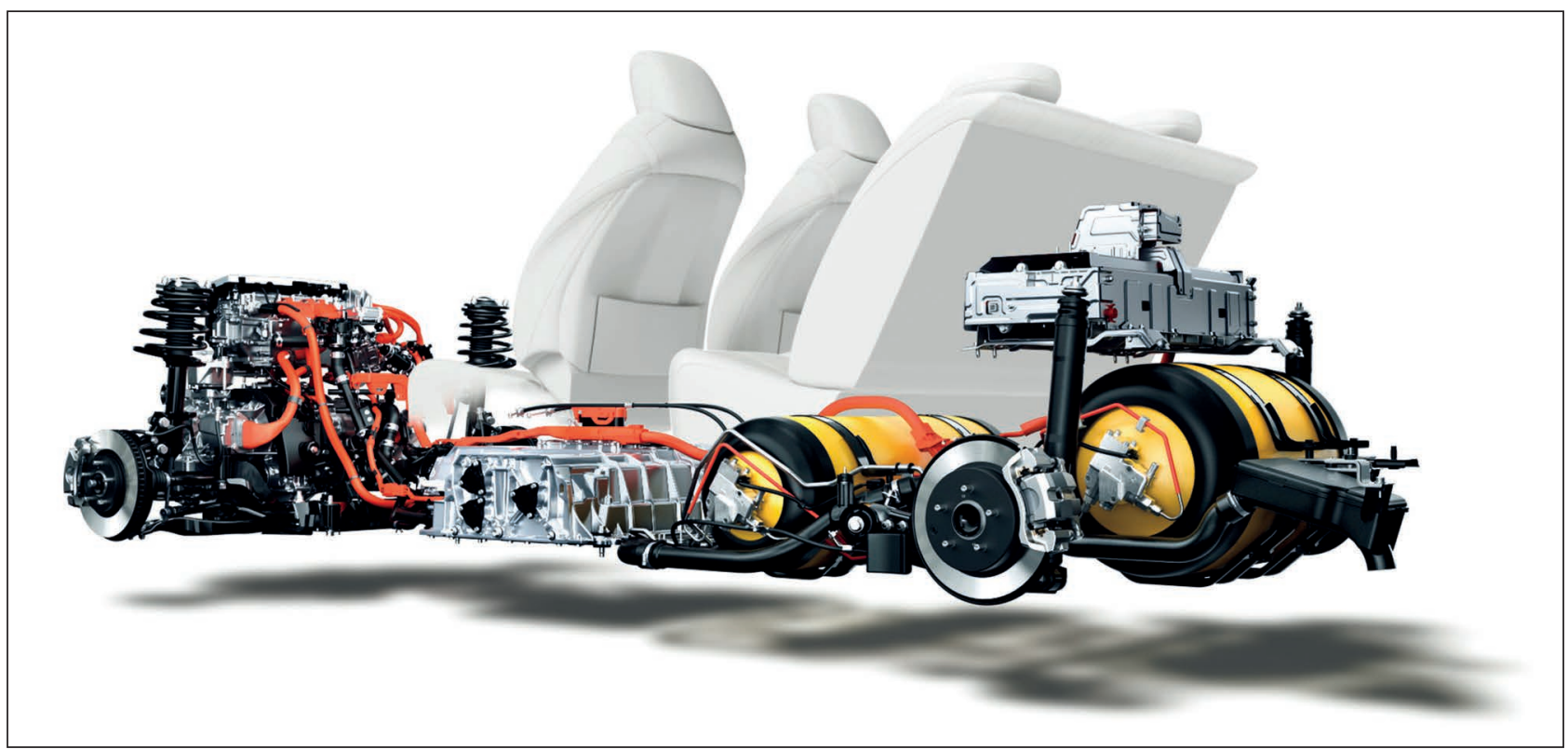

4. ábra. A Toyota Mirai hidrogéncellás szedán meghajtórendszerének ábrája

A járműben két hidrogéntank található, együttesen 4 kg hidrogént képesek tárolni. Kialakításuk és anyagválasztásuk olyan, hogy akár a közelről leadott pisztolylövéseknek is ellenállnak. Amennyiben a jármű szenzorjai olyan mértékủ lassulást érzékelnek, amely megfelel egy baleset által szolgáltatott értéknek, akkor egy biztonsági szelep kiengedi a tárolt hidrogént, amely - mivel a legkönnyebb előforduló elem a földön -, gyorsan elillan a levegőben, megakadályozva annak esetleges kigyulladását.

A Toyota Mirai hajtásláncának felhasználásával készültek a különféle kialakítású tömegközlekedési eszközök, buszok is, amelyek közül a Toyota Sora busz, két Mirai hidrogéncella felhasználásával, $2 \times 110$ kW teljesítmény leadására képes. A 22 ülő és 56 álló utas szállítására kialakított busz érdekessége, hogy a hidrogéncellákból villamos energia nyerhető álló helyzetben is, amely energia segítségével állóhelyi fogyasztók is táplálhatók $9 \mathrm{~kW}$ teljesítményig. A 2024-es Tokiói Olimpiai Játékokra 100 db ilyen hidrogéncellás autóbusz rendszerbe állítását tervezik.

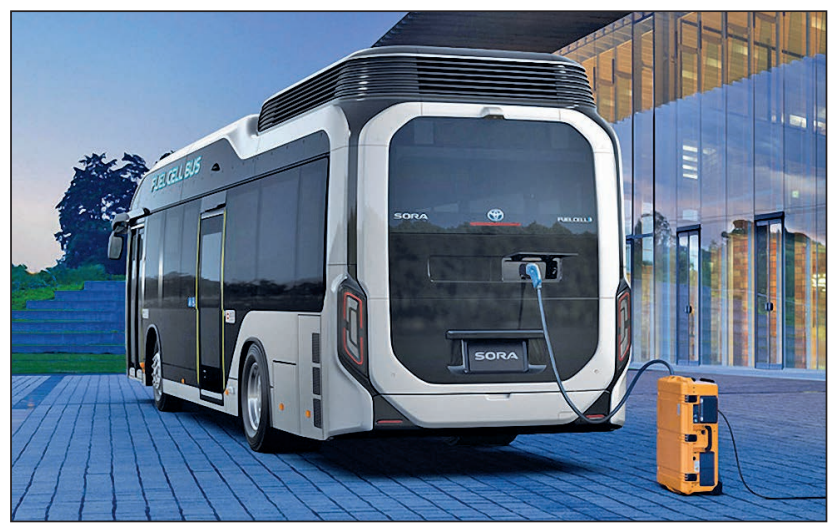

5. ábra. A Toyota Sora városi autóbusz

Szintén a Mirai üzemanyagcellákból fejlesztette ki a Los Angeles-i Toyota Logistics Systems (TLS) vállalat az „Alpha Truck” fantázianevű nyerges vontatóját. Természetesen az üzemanyagcellák nem az eredeti villanymotorokat hajtják meg ebben a teherautóban, hanem egy fokozott

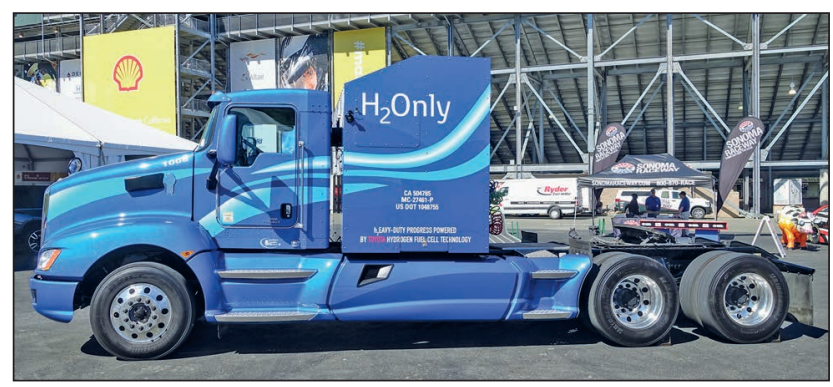

6. ábra. Az Alpha Truck Los Angeles-i bemutatója

igénybevételre kifejlesztett $250 \mathrm{~kW}$ teljesítményű villanymotor hajtja meg a kerekeket. Ennek megfelelően, és a rendelkezésre álló 40 kg-nyi hidrogénnel mintegy 2000$2200 \mathrm{~km}$-t tud megtenni. Eddig több mint $15000 \mathrm{~km}-\mathrm{t}$ tettek meg vele minden gond nélkül, és a használat során begyűjtött tapasztalatok alapján világossá vált az elektromos hajtás előnye, hogy a belsőégésű motorokkal ellentétben már az induláskor hatalmas nyomaték áll rendelkezésre, amelyet a rendszer a gyorsítási szakaszban is folyamatosan képes biztosítani.

Általánosságban elmondható, hogy a hidrogéncellás meghajtási rendszerek nagy jövő előtt állnak, kiemelten a tehergépjármúvek és a közösségi, tömegközlekedési járművek körében még akkor is, ha a járművek jelenleg alacsonyabb hatásfokkal és drágábban üzemeltethetők, mint a hibrid, vagy akár a belsőégésű motorral hajtott társaik. Ezen felül jelenleg még alacsony a hidrogénkutak elterjedt-

7. ábra. Bart Biebuyck, az FCH JU elnöke demonstrálja a hidrogéncellás hajtás "melléktermékének" biztonságos felhasználhatóságát
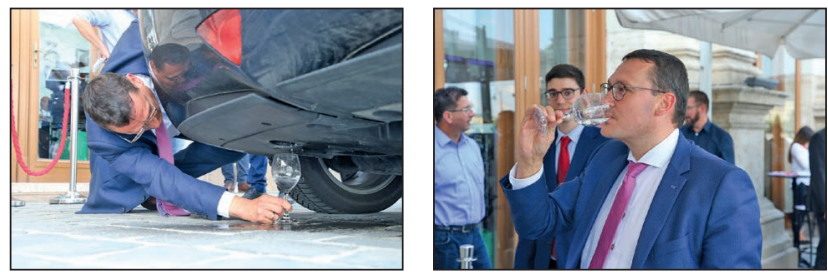
sége, ezzel együtt kevés üzem vagy vállalat foglalkozik a hidrogén előálításával, annak tárolásával és elosztásával. Nem szabad azonban azt sem elfelejteni, hogy a hidrogéncellás meghajtórendszer egyik nagy előnye jelenleg, hogy melléktermékként (égéstermékként) mindössze tiszta víz szabadul fel.

\section{A HIDROGÉNCELLÁK LEHETSÉGES KATONAI ALKALMAZÁSA}

A korábban említett előnyös tulajdonságai miatt a PEM cellás rendszerek védelmi szférában történő felhasználását számos helyen kutatják. Ismert tény, hogy a korszerű haderők egyre nagyobb mértékben függenek a villamos energiától, amely nemcsak a béke időszaki működésben és a tábori elhelyezésben érhető tetten, hanem a harcmezőn is. Mind a korszerű harceszközök, mind az egyéni katonák felszerelése egyre több elektromos eszközt tartalmaz. Ezek köre a jövőben várhatóan még bővülni fog, energiaellátásuk napjaink egyik legfontosabb logisztikai problémája. Ezen a körön belül van néhány olyan pont is, ahol a hidrogéncellák alkalmazása rendkívül előnyös lehet. Az alább felsorolt esetekben több állam hadserege, illetve nemzetközi szervezetek is folytatnak kutatásokat.

Egy gyalogos katona málhájának már most is igen jelentős részét teszik ki az akkumulátorok. Ha meg lehetne oldani ezek műveleti területen történő újratöltését, az nagyban növelné a katonák független alkalmazásának idejét. Léteznek olyan kis méretú aggregátorok, amelyekkel fel lehet tölteni egy raj vagy szakasz akkumulátorait, de hasonló méret és tömeg mellett erre egy PEM cella is képes lehet, ráadásul hang nélkül.

A békemissziók egyik legsebezhetőbb pontját képezik az utánpótlást szállító konvojok. Ha egy állandó tábor villamosenergia-ellátására pl. napelemeket alkalmaznak, az nyilvánvalóan csökkenti az aggregátorokba szükséges üzemanyag mennyiségét, ami redukálja a szükséges utánpótlást. Rossz idő esetére bizonyos mennyiségű akkumulátort is beépítenek ezekbe a korszerű tábori áramellátó rendszerekbe. A jelenlegi múveleti területeken az éghajlat okán ez többnyire nem jelent súlyos korlátot, de mérsékelt vagy hideg égövi területeken már versenyképes lehet a napelemes vízbontás - PEM cella kombinációja.

A korszerű harcjárművek számos villamos berendezést hordoznak, amelyeket álló helyzetben is üzemeltetni kell. llyenkor többnyire járatják a jármű motorját, de az nem csupán a zaj miatt kellemetlen, hanem csökkenti az eszköz hatótávolságát is. El lehet látni a járművet további akkumulátorokkal is, de ez jelentős tömegnövekedést von maga után és rontja a mozgékonyságot. Sok esetben telepítenek az ilyen járművekre kiegészítő, állóhelyzeti áramforrást. Ez ugyan szintén növeli a tömeget és fogyasztja az üzemanyagot, de mivel ezek a mini aggregátorok a fő hajtóművel ellentétben erre a feladatra vannak optimalizálva, alkalmazásuk hatékonyabb. Bár a logisztikai ellátási láncba nem szerencsés egy újabb üzemanyagfajtát bevonni, ebben az esetben mégis előnyös lehet, hiszen, ha az állóhelyzeti aggregátor helyett PEM cellát alkalmazunk. Ez lényegében hasonló mértékben rontja a harcjármü bizonyos paramétereit, de észrevétlenül működik, így nagyban növelhető a hordozó eszköz túlélőképessége.

Ahogy korábban is láthattuk, a PEM cellás - elektromos gépjármű-hajtáslánc bizonyos dimenziókban csaknem azonos, vagy akár azt meghaladó mozgékonyságot képes biztosítani, mint a hagyományos dugattyús motorok, miközben nem kell számolni a zajjal és a nagy hőkibocsátással. Ezek a tulajdonságok ideálissá teszik egy könnyű felderítő

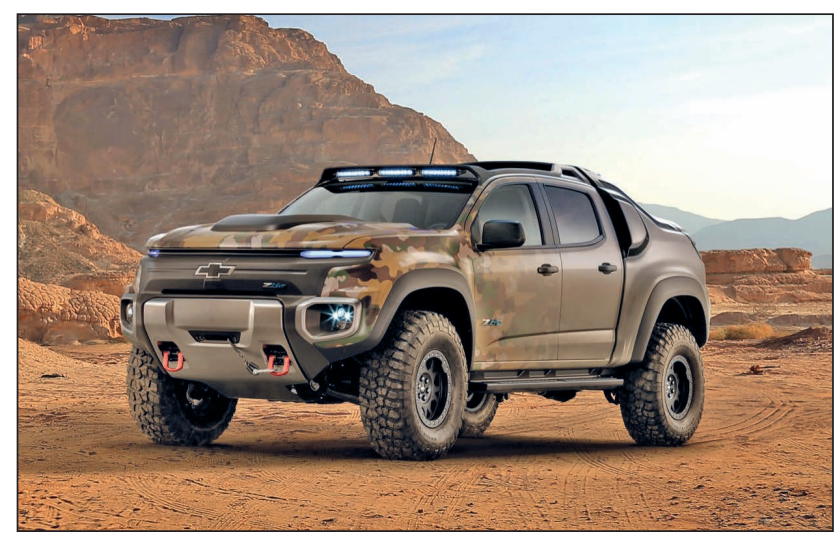

8. ábra. A Fort Carsonban tesztelt Chevrolet Colorado ZH2 terepjáró (General Motors)

(harc)jármű platformjaként. A hidrogénnel való feltöltés nem jár zajjal és csupán rövid ideig tart, így az ilyen jármű ellenség által történő felderítése meglehetősen nehézkes lehet. A hidrogéntároló tartályok megfelelő ballisztikai védelemmel történő ellátása lehetővé teszi az eszköz biztonságos harctéri üzemeltetést is. A US ARMY TARDEC ${ }^{14}$ a General Motorssal karöltve kísérleteket folytat már több mint 1 éve egy Chevrolet Colorado ZH2 típusú, hidrogéncellákkal felszerelt terepjáró gépjárművel [9].

\section{A HIDROGÉNCELLÁK TOVÁBBI FEJLESZTÉSI LEHETŐSÉGEI}

Általában igaz, hogy Európa a jelenleg legkorszerübbnek számító lítium-alapú akkumulátoroknak mind a gyártása, mind a fejlesztése területén komoly lemaradásban van Észak-Amerikához és Kínához képest. Ennek számos egyéb tényező mellett az is az oka, hogy lényegében Európa az egyetlen kontinens, ahol sem lítiumot, sem ritkaföldfémeket nem lehet rentábilis módon kitermelni, míg (ha eltekintünk a katalizátorhoz szükséges platinától) a PEM cellák esetében nincs ilyen korlát. Így nem csoda, hogy Európában számos helyen élénken dolgoznak a hidrogén szélesebb körű alkalmazásán, illetve, hogy az üzemanyagcellák fejlesztésének másik élharcosa az a Japán, amely szinte minden ásványi kincsből behozatalra szorul.

A hidrogén alkalmazásával kapcsolatban mára már sok probléma jól kezelhetővé vált. A közhiedelemmel ellentétben a hidrogén egyáltalán nem veszélyesebb a kőolajszár-

9. ábra. Az U 31-es a német haditengerészet legújabb, U 212 osztályú tengeralattjárója, amelyet üzemanyagcellás AIP-rendszerrel láttak el

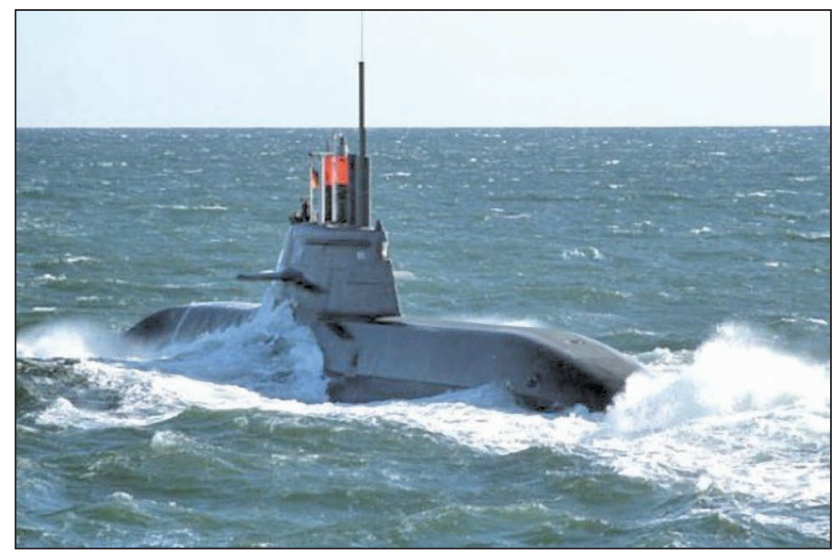




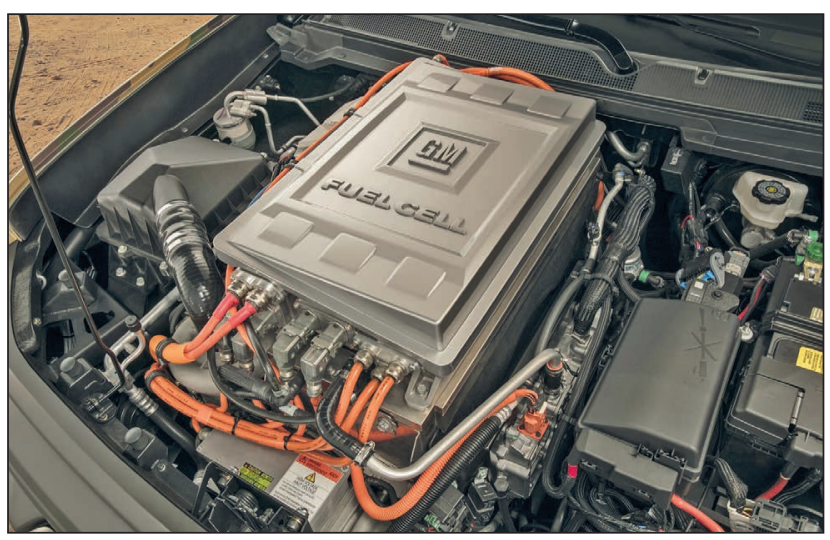

10. ábra. A Fort Carsonban tesztelt Chevrolet Colorado ZH2 terepjáró „erőműve”

mazék alapú üzemanyagoknál. Mivel igen nagy az energiasűrǔsége, nem okoz jelentős problémát a tártolásra szolgáló tartályok robosztus kialakítása. A legkorszerübb, a hidrogén üzemű gépkocsikban alkalmazott tartályok könynyedén ellenállnak bármilyen ütközésnek vagy akár kézifegyverek lövedékeinek is.

Az elektródák felületnövelése még mindig napirenden van, de a nanotechnológia révén itt még jelentős fejlesztési potenciál rejlik, illetve a teljesítménysűrűség növelése külső eszközökkel (szuperkondenzátorok) is megoldható.

A hidrogén üzemanyagcellák széleskörű elterjedéséhez a legfontosabb jelenleg fejlesztendő területek az alábbiak:

- A cellák árának mérséklése a katalizátorként alkalmazott platina részleges vagy teljes kiváltásával.

- Az elektródák és a katalizátor-réteg öregedésének mérséklése, a cellák üzemidejének növelése.

- A kevésbé tiszta, ezért sokkal olcsóbban előállítható hidrogén alkalmazhatóságának megoldása.

Ezeken a területeken Magyarország még Európán belül is viszonylag jó pozíciókkal bír, hiszen a Magyar Tudományos Akadémia Természettudományi Kutatóközpontjának Anyag- és Környezetkémiai Intézetében ${ }^{15}$ már évtizedek óta kutatják a témát, és e tevékenységük nemzetközileg is elismert.

\section{ÖssZEFOGLALó}

A hidrogénüzemű PEM cella egy olyan technológia, amelyben Magyarország számára is jelentős alkalmazói és fejlesztési potenciál rejtőzik. A haditechnikában történő felhasználása olyan eszközöket eredményezhet, amelyek bizonyos egyedülálló tulajdonságaik által jelentős műveleti előnyt biztosíthatnak az alkalmazó katonai egységek számára. A technika széleskörű elterjedése ugyanakkor pozitív hatással lehetne Magyarország energiabiztonságára is.

A PEM cellák jelen állapotukban is érdemesek arra, hogy egyes katonai eszközökben történő alkalmazásuk megfontolás tárgyát képezze és ezekből magas készenléti szintű fejlesztések, prototípusok készüljenek. Hosszabb távlatban gondolkodva pedig a technológiához kapcsolódó alapkutatások, elsősorban anyagtechnikai fejlesztések hozhatnának előrelépést.

Az Európai Unióban mindkét fejlesztési irány komoly támogatásnak örvend, így a nemzetközi projektekben való részvétel lehetősége is adott, de az MTA TTK AKI révén Magyarország önállóan is sikerre vihet bizonyos részkutatásokat vagy létrehozhat magas műszaki színvonalú haditechnikai eszközöket.

\section{FELHASZNÁLT IRODALOM}

[1] Key World Energy Statistics 2017, International Energy Agency. DOI: 10.1787/key_energ_stat-2017-en;

[2] Stolten, Detlef \& Emonts, Bernd: Fuel cell science and engineering materials, processes, systems and technology, Wiley-VCH, Weinheim, 2012. DOI: 10.1002/9783527650248;

[3] Szűr Zoltán: Az U212 osztályú üzemanyagcellás tengeralattjáró, Haditechnika, 2005/2,3.;

[4] Wu, Yuping: Lithium-ion batteries; fundamentals and applications, CRC Press, 2015, Boca Raton. DOI: 10.1201/b18427;

[5] Fuel Cells and Hydrogen Joint Undertaking szóróanyag;

[6] Mayer Zoltán: Hidrogén-mobilitás és lehetséges szinergiái a közlekedési és energetikai rendszerekkel, a Magyar Hidrogén és Tüzelőanyag-cella Egyesület 2018. május 23-i előadása;

[7] Toyota Central Europe Kft.: A hidrogén jelene és jövője, 2018. májusi 23-i előadása;

[8] Field, Kyle: Toyota Explores The Potential Of A Hydrogen Fuel Cell Powered Class 8 Truck, CleanTechnika, 2018.04.27, https://cleantechnica. com/2018/04/27/toyota-explores-the-potential-of-ahydrogen-fuel-cell-powered-class-8-truck/ [Letöltve: 2018. július 03];

[9] Diamond, Christopher: Army begins testing off-road vehicle powered by hydrogen fuel cell, ArmyTimes, 2017.08.07;

https://www.armytimes.com/news/your-army/2017/07/11/ army-begins-testing-off-road-vehicle-powered-byhydrogen-fuel-cell/ [Letöltve: 2018. július 04].

\section{JEGYZETEK}

1 A primer energiák azok az energiaformák, amelyek a természetben is megtalálhatók. Ilyenek a fosszilis energiák, a maghasadás és a szél, a víz vagy a nap energiája, vagyis az energiahordozók. 2 2008-ban kb. 35 TWh, 2017-ben 45 TWh.

3 A szekunder energiák általában nincsenek jelen a természetben, ezeket az ember állítja elő a primer forrásokból. Ilyen a motorbenzin vagy a villamosság is.

4 A távvezetékek vesztesége elhanyagolható pl. a kőolajszármazékok szállítási költségeihez képest.

$5 \mathrm{Az}$ energia koncentrációja a térfogat vagy a tömeg arányában, pl. $\mathrm{Wh} / \mathrm{kg}$ vagy $\mathrm{MJ} / \mathrm{m}^{3}$.

6 A hagyományos erőművekben használt eljáráshoz hasonlóan a hidrogént elégetve, majd a felszabaduló hőenergiával vizet forralva és azzal turbinát meghajtva is lehetséges az áram termelése.

7 Egyebek között a metanolos cella kifejlesztéséért kapott 1994-ben Nobel-díjat a magyar származású amerikai vegyész, Oláh György.

8 Proton Exchange Membrane - vagyis „protoncsere membrán”, a magyar terminológiában a „proton áteresztő membrán” megnevezés is használatos.

9 A generátorok hatásfoka akár $98-99 \%$ is lehet, de a generátort meghajtó hőerőgépek (dugattyús motor, esetleg gázturbina) termikus hatásfoka csupán $24-40 \%$.

$10 \mathrm{Az}$ akkumulátorok esetében az élettartamot töltési/kisütés ciklusban mérik. Egy akkumulátort akkor tekintünk „,selejtnek”, ha már csak az eredeti érték $80 \%$-ára lehet feltölteni, ami manapság jellemzően 1000-2000 ciklus.

11 Cseppfolyós állapotban. A töltőnyomás emelésével az energiasűrűség is növelhető.

12 CHP - Combined Heat and Power units, azaz kombinált fütő és energiaellátó egységek.

13 Fuel Cells and Hydrogen Joint Undertaking 2017. december 31-i adat.

14 Tank Automotive Research, Development and Engineering Center. 15 MTA TTK AKI. 